Provided by the author(s) and University of Galway in accordance with publisher policies. Please cite the published version when available.

\begin{tabular}{|c|c|}
\hline Title & $\begin{array}{l}\text { Gender equality policy and gender mainstreaming in Irish Aid: } \\
\text { From diffusion to dilution to disappearance }\end{array}$ \\
\hline Author(s) & Reilly, Niamh \\
\hline $\begin{array}{l}\text { Publication } \\
\text { Date }\end{array}$ & 2013 \\
\hline $\begin{array}{l}\text { Publication } \\
\text { Information }\end{array}$ & $\begin{array}{l}\text { Reilly, Niamh. (2013). Gender equality policy and gender } \\
\text { mainstreaming in Irish aid: From diffusion to dilution to } \\
\text { disappearance. Irish Studies in International Affairs, } 24,237 \text { - } \\
257 \text { doi: } 10.3318 / \text { ISIA.2013.24.9 }\end{array}$ \\
\hline Publisher & Royal Irish Academy \\
\hline $\begin{array}{l}\text { Link to } \\
\text { publisher's } \\
\text { version }\end{array}$ & https://dx.doi.org/10.3318/ISIA.2013.24.9 \\
\hline Item record & http://hdl.handle.net/10379/15621 \\
\hline DOI & http://dx.doi.org/10.3318/ISIA.2013.24.9 \\
\hline
\end{tabular}

Downloaded 2023-04-26T12:29:56Z

Some rights reserved. For more information, please see the item record link above. 


\title{
Gender Equality Policy and Gender Mainstreaming in Irish Aid: From Diffusion to Dilution to Disappearance?
}

Niamh Reilly

School of Political Science and Sociology, NUI Galway

\begin{abstract}
This article offers a critical analysis of Irish Aid's treatment of gender equality and gender mainstreaming. Informed by key concepts in policy process and feminist scholarship, it examines the evidence of Irish Aid's progress in this area. The author finds that gender equality has low salience in Irish Aid and a record of weak implementation. It is argued that while the adoption of a gender equality policy in Irish Aid reflects global policy diffusion, Ireland's rhetorical endorsement of gender equality in international affairs stems chiefly from an instrumental interest in the reputational gains it can offer and represents a form of 'soft coercion' rather than a principled interest in achieving gender equality. The weakness of state feminism in Ireland and the weak links between officials and women's movement actors are also factors. Further, while the disadvantage of low salience can be offset by the presence of effective 'policy entrepreneurs' using discretionary power to augment resources, this is not evident in Irish Aid in the case of the Gender Equality Policy. Furthermore, the rising paradigm of 'managing for development results' poses new challenges to rights-based approaches to development, including gender mainstreaming. For these reasons, the Gender Equality Policy in Irish Aid is at risk of continued dilution and perhaps disappearance.
\end{abstract}

\section{INTRODUCTION}

The Beijing Platform for Action agreed at the Fourth UN World Conference on Women (Beijing, 1995) is widely credited with spurring the global diffusion of 'gender mainstreaming' as the new standard strategy to achieve gender equality. Originating in gender and development and women's movements, gender mainstreaming was envisaged as a transformative paradigm that built upon, but went beyond, women's equality with men. In particular, the 'twin track' approach to gender mainstreaming was intended to be a powerful mechanism, whereby every aspect of policy formation would be scrutinised from a critical gender perspective with a view to redressing deeply engrained gender disadvantage (and advantage) and forging a more just society in the process. Importantly, gender mainstreaming was not intended to supplant targeted policies aimed at empowering women and remedying historic disadvantage. Irish Aid embraced gender mainstreaming officially as the principal strategy of its gender equality policy in $2004 .{ }^{1}$ This was not a completely new departure, however. In 1986, Ireland's development co-operation programme adopted a 'women in development' policy. Following Beijing, gender was named as a cross-cutting priority and gender equality was included in the government of Ireland's 1996 White Paper on Foreign 
Policy. ${ }^{2}$ In 2003, a review of progress in advancing gender equality in Ireland's development programming concluded that 'gender mainstreaming as a strategy is not well understood or practiced and institutional arrangements for supporting gender mainstreaming are weak'.

This article offers a critical analysis of the progress made by Irish Aid in implementing its gender equality policy to date. It is based primarily on a review of available policy documents and reports, informed by key concepts in policy process theory and in feminist scholarship on gender mainstreaming. The first section provides a brief review of selected literatures and identifies those concepts that are most relevant to explaining and interpreting the record of Irish Aid in implementing its gender equality policy. The second section considers the available evidence of Irish Aid's progress in this area, drawing on concepts of policy process and feminist theory to discuss these findings. I argue that little has changed in the ten years since the 2003 review. The commitment to and implementation of gender equality and gender mainstreaming in Irish Aid continues to be weak and is at risk of further dilution and perhaps even disappearance.

\section{POLICY PROCESS THEORISING AND GENDER MAINSTREAMING}

The term 'policy process' captures an array of policy-related activities, generally accepted to include: agenda-setting, policy formulation, decision making, implementation, and evaluation. ${ }^{4}$ In this section I flag some of the key tenets of different theories of the policy process and consider their relevance and applicability in light of feminist scholarship on gender mainstreaming. In doing so, I aim to identify analytical concepts that are especially helpful in understanding and interpreting the story of gender mainstreaming in Irish Aid, which will be discussed in detail in the second section. In particular, I suggest that theories of policy diffusion are most relevant to this task (incorporating social constructivism).

In a recent review of research and emerging trends in policy process theory, Mathew Nowlin identifies six principal approaches or frameworks. ${ }^{5}$ These are: institutional analysis and development; multiple streams; the advocacy coalition framework; policy diffusion; punctuated equilibrium; and social constructivism and policy design. ${ }^{6}$ Harald Saetren has also identified a sizeable literature, generally overlooked in the mainstream policy process literature, which addresses a range of 'policy implementation' issues in areas from health and education to law, environment and economics. ${ }^{7}$ In addition, a substantial, cross-disciplinary literature on gender mainstreaming is also largely overlooked in policy process scholarship. This body of work is chiefly concerned with understanding how feminist ideas get translated into policy and assessing whether or not, in what ways, and under what conditions gender mainstreaming has succeeded as a strategy to advance gender equality. While much gender mainstreaming scholarship emanates from the feminist corners of politics and policy

\footnotetext{
${ }^{1}$ Department of Foreign Affairs, Development Cooperation Ireland (hereafter cited as DFA DCI), Gender Equality Policy (Dublin, 2004), available at:

http://www.irishaid.gov.ie/media/irishaid/allwebsitemedia/20newsandpublications/publicationpdfsenglish/irishaid-gender-equalitypolicy-april-2004.pdf (10 June 2013).

2 Department of Foreign Affairs, Challenges and opportunities abroad: White Paper on Foreign Policy (Dublin, 1996).

${ }^{3}$ DFA DCI, Gender Equality Policy, 10.

${ }^{4}$ W. Jann and K. Wegrich, 'Theories of the policy cycle', in F. Fischer, G.J. Miller and M.S. Sidney (eds), Handbook of public policy analysis: theory, politics, and methods (Boca Raton, FL, 2007), 43-62: 43.

5 Matthew C. Nowlin, 'Theories of the policy process: state of the research and emerging trends', Policy Studies Journal 39 (S1) (2011), 41-60.

${ }^{6}$ Nowlin, 'Theories of the policy process', 41.

${ }^{7}$ Harald Saetren, 'Facts and myths about research on public policy implementation: out-of-fashion, allegedly dead, but still very much alive and relevant', Policy Studies Journal 33 (4) (2005), 559-82.
} 
disciplines, ${ }^{8}$ scholars in development studies, ${ }^{9}$ sociology ${ }^{10}$ and gender studies ${ }^{11}$ have also made significant contributions to gender mainstreaming debates.

Scholarship on issues of 'implementation' in policy process literature is especially relevant to the analysis of gender mainstreaming as a policy practice. The tenth anniversary of the Beijing Platform for Action in 2005 (Beijing +10) sparked a great deal of discussion among activists and scholars about whether gender mainstreaming, the flagship strategy of the Platform, was working. Most concluded that in the decade following the widespread diffusion of gender mainstreaming in 1995, there had been 'a failure to sustain the interest and commitment of governments and international development agencies in women's empowerment'. ${ }^{12}$ Some argue, however, that all is not lost and that gender mainstreaming still has transformative potential that can be realised if it is understood as an evolving, incremental process. ${ }^{13}$ Caroline Moser, for example, argues for technical solutions, including the systematic breakdown of gender mainstreaming implementation into stages linked to carefully designed and applied indicators to underpin monitoring and evaluation. ${ }^{14}$ Similarly, Sophie Jacquot underlines that the success of gender mainstreaming relies not on processes of 'legislative or institutional creation' but 'only on administrative routines'. ${ }^{15}$

From this perspective, analysing the successes and failures of gender mainstreaming requires that particularly close attention be paid to what has been dubbed in policy process theory as the 'missing link' or 'black box' of implementation. ${ }^{16}$ At the same time, when gender mainstreaming is understood as a process, the commonly used distinction between 'policy-making' and 'policy implementation' is inadequate, because it fails to appreciate the ways in which decisions about 'administrative routines' are de facto policy making or policy formation decisions. This puts the spotlight on the role of bureaucrats and the discretionary power they exercise at different levels. Michael Lipsky is best known for his focus on bureaucrats as policy actors who: 'believe themselves to be doing the best they can under adverse circumstances, and...develop techniques to salvage service and decision-making

${ }^{8}$ See, for example, Sophie Jacquot, 'The paradox of gender mainstreaming: unanticipated effects of new modes of governance in the gender equality domain', West European Politics 33 (1) (2010), 118-35; Mieke Verloo, 'Mainstreaming gender equality in Europe: a critical frame analysis approach', Greek Review of Social Research 117 (B) (2005), 11-34, available at: http://www.grsr.gr/pdf/117_11-34.pdf (10 June 2013); Jacqui True, 'Mainstreaming gender in global public policy', International Feminist Journal of Politics 5 (3) (2003), 368-96; Shirin M. Rai (ed.), Mainstreaming gender, democratizing the state? Institutional mechanisms for the advancement of women (Manchester, 2003); Mark A. Pollack and Emilie Hafner-Burton, 'Mainstreaming gender in the European Union: getting the incentives right', Journal of European Public Policy 7 (3) (2000), $432-56$.

${ }^{9}$ For example, Prudence Woodford-Berger, 'Gender mainstreaming: what is it (about) and should we continue doing it?', in Andrea Cornwall, Elizabeth Harrison and Ann Whitehead (eds), Feminisms in development: contradictions, contestations and challenges (London, 2007), 122-34; Caroline Moser, 'Has gender mainstreaming failed?', International Feminist Journal of Politics 7 (4) (2005), 576-90.

${ }^{10}$ For example, Sylvia Walby, 'Introduction: comparative gender mainstreaming in a global era', International Feminist Journal of Politics 7 (4) (2005), 453-70, available at:

http://www.lancs.ac.uk/fass/sociology/papers/walby-ComparativeGenderMainstreaming.pdf (10 June 2013).

${ }^{11}$ See Teresa Rees, 'Reflections on the uneven development of gender mainstreaming in Europe', International Feminist Journal of Politics 7 (4) (2005), 555-74.

${ }^{12}$ Rosalind Eyben, 'Subversively accommodating: feminist bureaucrats and gender mainstreaming', IDS Bulletin 41 (2) (2010), 54-61: 1.

${ }^{13}$ Caroline Moser; Joan Eveline and Carol Bacchi, 'What are we mainstreaming when we mainstream gender?', International Feminist Journal of Politics 7 (4) (2005), 496-512; Eyben, 'Subversively accommodating'.

${ }^{14}$ Moser, 'Has gender mainstreaming failed?'.

15 Jacquot, 'The paradox of gender mainstreaming', 127, emphasis added.

${ }^{16}$ Michael Hill and Peter Hupe, Implementing public policy (2nd edn, Los Angeles, CA, 2009), 42. 
values within the limits imposed on them by the structure of the work' ${ }^{17}$ This understanding of the role of the 'street-level' bureaucrat is important to bear in mind in interpreting the progress which has been made in the implementation of Irish Aid's gender equality policy via gender mainstreaming. The rest of this section highlights key concepts in policy process theory with a focus on their relevance to understanding and interpreting the story of gender mainstreaming in Irish Aid.

Of all the contemporary theories of policy processes, policy diffusion is perhaps the most relevant paradigm for the purposes of this article, not least because it enables analysis both of the conditions of policy diffusion and of what happens after initial policy adoption. Policy diffusion theory seeks to explain 'how similar policy innovations are adopted across states in the American context or across countries in comparative perspective'. ${ }^{18}$ More broadly, Frank Dobbin et al. offer an account of global policy diffusion which includes a variety of concepts and theoretical propositions that are useful for interpreting the trajectory of the gender equality agenda in Irish development aid policy. ${ }^{19}$ Specifically, the authors identify four distinct currents of scholarship, each homing in on a different practice or dynamic to explain various patterns of global policy diffusion. These are: social construction, coercion, competition and policy learning. ${ }^{20}$

Social constructionist and learning approaches view the policy diffusion process as a benign one in which norms, ideas and knowledge gain currency and acceptance which, ultimately, lead to policy adoption or innovation. Learning theorists underline 'rational', evidence-based, learning as a driver of policy change whereby new information, data or scientific evidence is taken on board by policy actors. ${ }^{21}$ There is evidence (discussed below) that some policy learning of this kind takes place in Irish Aid at the bureaucratic level of operationalisation of gender mainstreaming. This includes, for example, learning through participation in the OECD or Irish Aid gender networks or through Irish Aid's regular engagement of 'experts'. Initial diffusion of policy across countries, however, is thought to gather momentum when leading countries act as exemplars, or when expert groups, including prominent NGOs and networks, promulgate or champion a new policy. ${ }^{22}$ Margaret Keck and Catherine Sikkink, for example, have analysed the pivotal role of transnational networks in norm diffusion, citing the now widespread acceptance that violence against women violates human rights and the adoption of related policy changes. ${ }^{23}$ In a review of feminist literature on gender mainstreaming, Sylvia Walby also confirms the influence of social constructionist and policy learning explanations. She notes that the following factors are prominent in theorisations of the gender mainstreaming policy processes: 'advocacy by civil society groups and movements within a country;...epistemic communities and expert networks; ...drawing on the legitimation [sic] of universal human rights; [and] isomorphic development with the European organisational field...' ${ }^{24}$

${ }^{17}$ Michael Lipsky, Street-level bureaucracy: dilemmas of the individual in public services (New York: Russell Sage Foundation, 2010), xv.

18 Nowlin, 'Theories of the policy process', 48.

${ }^{19}$ Frank Dobbin, Beth Simmons and Geoffrey Garrett, 'The global diffusion of public policies: social construction, coercion, competition, or learning?' Annual Review of Sociology 33 (2007), 449-72, available at: http://scholar.harvard.edu/dobbin/files/2007_ars_dobbin_simmons.pdf (10 June 2013).

${ }^{20}$ Dobbin et al., 'The global diffusion of public policies'.

21 Dobbin et al., 'The global diffusion of public policies', 461.

22 Dobbin et al., 'The global diffusion of public policies', 452.

${ }^{23}$ M.E. Keck and K. Sikkink, Activists beyond borders: advocacy networks in international politics (Ithaca, NY: Cornell University Press, 1998).

${ }^{24}$ Walby, 'Introduction: comparative gender mainstreaming', 458. 
So, does the constructionist view (i.e., the hypothesis that the spread and acceptance of ideas drives policy change) explain the adoption of gender equality and gender mainstreaming by Irish Aid? Unlike Sweden, where Woodford-Berger describes the enthusiastic adoption of gender mainstreaming as stemming from 'a firm belief in and commitment to the production of gender equality', a similar claim is not plausible in the case of Irish Aid. ${ }^{25}$ It is well known that the gender equality agenda in Ireland was slow to take off and that meaningful gains (e.g., in women's workplace equality and rights) were achieved primarily under pressure from the European Union. Moreover, Ireland is a post-colonial state and small open economy that has struggled to achieve 'development' and, at the time of writing, is a programme country of the EU and IMF. As such, it generally occupies a weaker position vis-à-vis other 'developed' countries in the complex of asymmetrical relationships that structure international relations and global policy agenda setting. From this perspective, policy diffusion theory concepts of 'imitation', 'soft coercion' and, more indirectly, 'competition' offer more traction in explaining and understanding why and how gender mainstreaming came to be adopted as Irish Aid's declared strategy for the advancement of gender equality. Moreover, the influence of such dynamics in the origins of gender mainstreaming in Irish Aid undoubtedly continue to shape the nature and the quality of its implementation post-adoption.

Imitation or mimicry of policies can happen when policy-makers blindly copy the 'largest, richest, or fastest-growing' countries. ${ }^{26}$ Or, copying can be encouraged by the geographic closeness ${ }^{27}$ or the 'psychological proximity' of cities, states and countries. ${ }^{28}$ As will be discussed in detail in the following section, there is evidence that Irish Aid imitates its counterparts in countries like the United Kingdom and the United States (rather than in Denmark or Sweden). Ireland's minimalist approach to the level of development aid funds it allocates directly to women's equality organisations is one example. ${ }^{29}$ More significantly, however, the concept of 'coercion' is a helpful lens through which to consider the role that Irish Aid's gender equality policy might play in Ireland's diplomatic repertoire. Coercive policy diffusion can occur through: the top-down imposition of conditionality; the exercise of 'policy leadership' by powerful players (for example, German fiscal policy translated into European Central Bank policy); or the exercise of hegemonic influence. ${ }^{30}$ The latter usually involves influential 'epistemic communities' and 'policy entrepreneurs' who dominate knowledge production and communication, making the ideas and imperatives of dominant groups appear to be 'common sense'. As noted, the majority of the legislative and policy changes that Ireland has introduced to advance women's rights and equality more generally over the past four decades have been driven by external pressure or coercion of some form. The most 'coercive' of these have been: EU equality directives (culminating in comprehensive equality legislation and the establishment of the Equality Authority); European Court of Human Rights judgments (e.g., decriminalising homosexuality); and the Good Friday Agreement (prompting the formation of the Human Rights Commission). UN human rights treaties (e.g., CEDAW) and 'soft law' (e.g., the Beijing Platform for Actionthe global policy document that calls for gender mainstreaming) all represent forms of soft coercion. As such, their power resides in the potential adverse impact on Ireland's reputation

25 Woodford-Berger, 'Gender mainstreaming', 127.

26 Dobbin et al., 'The global diffusion of public policies', 452.

27 Nowlin, 'Theories of the policy process', 48.

28 Dobbin et al., 'The global diffusion of public policies', 453.

${ }^{29}$ Organisation for Economic Co-operation and Development, 'Aid in support of gender equality and women's empowerment: statistics based on DAC members' reporting on the Gender Equality Policy Marker, 2009-2010' (Paris, 2012), available at: http://www.oecd.org/dataoecd/57/38/49732892.pdf (10 June 2013).

${ }^{30}$ Dobbin et al., 'The global diffusion of public policies', 456. 
that ignoring or breaching them could produce (e.g., in the form of diminished access to and approval of more powerful actors).

As noted, Ireland is small and relatively weak in terms of global power politics, military presence and diplomatic clout. In international relations, therefore, it relies greatly on its carefully-cultivated and maintained reputation in niche areas. This includes a demonstrable record of generous development aid directed at the world's poorest countries and well-regarded contributions to UN peace support operations. Arguably, we might expect gender equality and women's human rights to feature instrumentally in these areas of Ireland's flagship foreign policy. That is, Ireland will support gender equality and women's human rights agendas to the degree that the relevant policy actors perceive that this is 'required' - in a 'soft' if not binding way - by influential external actors and that doing so will benefit Ireland's reputation. Understanding the adoption of Irish Aid's gender equality policy (and its commitment to gender mainstreaming) as a response to soft coercion in this sense, and as a card that Irish policy actors play to achieve reputational goals, is helpful in explaining the wide gap between Irish Aid's very strong rhetorical commitment to gender equality and its seemingly weak record of action to implement its gender equality policy.

The explanatory power of competition in diffusion theory features most strongly in discussions of globalisation, which highlight that: '[w]hen a country's competitors simplify regulatory requirements, ameliorate investment risks, and reduce tax burdens, that country comes under pressure to follow suit'. ${ }^{31}$ The story of the rise of Celtic Tiger Ireland is one of pro-active policy diffusion and adoption along these lines, especially in creating conditions favourable to foreign direct investment, reducing the tax base, and light regulation of financial markets. A comparison of Celtic Tiger Ireland and gender mainstreaming in Irish Aid, however, is not just a matter of parallel and unconnected policy diffusion stories: one high-salience, grand in scale, and widely regarded as exemplary (until 2008); and the other (notwithstanding the rhetoric of the policy documents) low salience and low impact. Arguably, the weakness of the latter is linked to dominance of the former, which militates against 'unproductive' public expenditure, including investment in policy machineries to advance and monitor governmental implementation of its equality and human rights commitments. More directly, however, the deepening influence of free-market and business management logic is most evident in the burgeoning aid effectiveness agenda. ${ }^{32}$ This new hegemonic narrative in development aid circles and its focus on 'managing for development results' is the latest challenge for gender mainstreaming supporters who now must weigh the potential benefits of mainstreaming gender in the aid effectiveness agenda against the risks that gender equality will be finally overwhelmed in the process. ${ }^{33}$ Ireland is enthusiastically embracing the aid effectiveness agenda. ${ }^{34}$ Irish Aid's approach to gender equality and gender

31 Dobbin et al., 'The global diffusion of public policies', 457.

32 Organisation for Economic Co-operation and Development, 'The Paris Declaration on aid effectiveness and the Accra agenda for action', (Paris, 2005/2008), available at: http://www.oecd.org/dataoecd/11/41/34428351.pdf (10 June 2013).

33 Association for Women's Rights in Development, 'Inputs for the preparation of the Round Table 4 on managing for development results, 3rd high level forum, Accra, 2008: brief issue paper on managing for development results and gender equality' (AWID, 2008); Association for Women's Rights in Development, 'Key demands from women's rights organizations and gender equality advocates to the fourth high level forum on aid effectiveness (Busan, Korea, 2011) and the development cooperation forum (2012)', (AWID 2012), available at:

http://www.awid.org/content/download/123575/1397157/file/Women's\%20Key\%20Demands_Busan_updated_ Oct201.pdf (10 June 2013).

34 Nigel Thornton, Anne Barrington and Kevin Carroll, 'Joint evaluation of the Paris DeclarationPhase 2: donor HQ study-Irish Aid' (London: Irish Aid/Agulhas, 2010), available at: http://www.oecd.org/dataoecd/61/51/47083236.pdf (10 June 2013). 
mainstreaming is being construed significantly in terms of its place within the new dominant policy narrative. It remains to be seen if this will prove to be a boon for gender equality or contribute to its further dilution and perhaps disappearance.

In addition to the policy diffusion concepts, the work of policy process scholars who bring a social constructionist lens to policy design yields insights helpful to interpreting the path of gender equality in Irish Aid. This work calls on policy analysts to move beyond 'taking stated policy goals at their face value' and to focus instead on examining 'the meanings and assumptions within policy designs' as well as 'the designs' impact on social, political, and economic life', so that policy evaluation becomes a form of 'social critique'. ${ }^{35}$ Such a perspective is also evident in transformative understandings of gender mainstreaming, which view it as a framework to "scrutinize and reinvent processes of policy formulation and implementation across all issue areas and all levels... [in order] to address and rectify persistent and emerging disparities between men and women. ${ }^{36}$

Anne Schneider and Mara Sidney's findings on how the social construction of meaning shapes policy design, especially in relation to patterns in the status of different policy actors and target audiences, throws light on how and why gender equality and gender mainstreaming as policy practices per se are likely to be marginalised or invisible in various policy domains. Using empirical research, Schneider and Sidney have constructed a mapping of different groups in society according to their command of 'political resources', from lower to higher levels on one axis, and on the other axis, their perceived social worth, ranging from 'more positive' to 'more negative'. ${ }^{37}$ While based on the US context, their mapping resonates in many Western developed countries, including Ireland. Two things in particular stand out as relevant to this discussion of Irish Aid and its gender equality policy. First, Schneider and Sidney's findings suggest that 'poor' target groups have low levels of political clout and hover on the border between worthy 'dependent' and unworthy 'deviant'. Exacerbated by the fact that 'the poor' targeted by Irish development aid are abstract and generally construed through a lens of 'Third World other', Schneider and Sidney's mapping is a reminder of the powerlessness of this target population vis-à-vis domestic Irish politics. This bolsters the argument that policy formation, in this area, is determined mostly by Irish policy actors' concerns about reputation and to be seen 'to be doing the right thing' by influential external actors (and to a lesser extent perhaps by key development NGOs). Second, Schneider and Sidney's findings situate 'feminist' actors (in contrast to 'mothers') in the negatively perceived half of the scatter diagram, closer to 'deviants' than to 'contenders' and enjoying relatively low levels of political resources and policy influence. This insight helps to explain why any person (in particular a female) attempting to champion gender equality, inside or outside of policy formation roles, often begins with the handicap of being viewed as a 'deviant contender' and must engage and negotiate from this position. Such a disadvantaged position inevitably has implications for the opportunity structures and room to manoeuvre available to those who wish, or are obliged, to advance gender equality and gender mainstreaming, especially in organisations where there is little awareness of gender.

\section{State-feminism relationship}

Complementing policy process theory, the Research Network on Gender and the State (RNGS) has developed a valuable analytical framework for analysing the influence of

35 Anne Schneider and Mara Sidney, 'What is next for policy design and social construction theory?', The Policy Studies Journal 37 (1) (2009), 103-19: 114.

36 True, 'Mainstreaming gender in global public policy', 369, emphasis added.

${ }^{37}$ Schneider and Sidney, 'What is next for policy design and social construction theory?', 107. 
feminist ideas across a variety of public policy areas in post-industrial democracies ${ }^{38}$ The RNGS framework suggests that feminist approaches to policy are more likely to become effective state policy where state agencies for women's policy exist, are well-resourced and have strong links with women's movement activism. ${ }^{39}$ Gender mainstreaming has its roots in women's movement activism and as such may be described as a feminist policy (especially when promulgated in its 'twin track' and transformative forms). Hence, in seeking to explain the record of implementation of gender equality in Irish Aid, it is useful to consider the nature of state-feminist relations at play in this context and how this shapes the record on implementation of gender mainstreaming in the Irish Aid. The framework identifies four possible policy outcomes: (1) 'Dual response' is the strongest outcome from a feminist perspective, where women's movement actors are fully involved in policy formation and the resulting policies and practices reflect this influence; (2) 'Co-optation' describes situations where women's movement actors are included in aspects of policy processes, but the policies and practices that are put in place do not reflect their approaches; (3) 'Pre-emption' entails situations where women's movement actors are excluded but their ideas and language feature in policy formation; and finally (4) 'No response' describes situations where women's movement actors are not included and feminist ideas do not influence policy outcomes. ${ }^{40}$

In the case of gender mainstreaming in Irish Aid, it can be argued that the relationship is one that sits between 'co-optation' and 'pre-emption'. State feminism is extremely weak if it exists at all in Ireland. The state 'women's machinery' consists of a small Gender Equality Division in Department of Justice, Defence and Equality, a senior gender advisor and a number of 'gender focal points' across Irish Aid, and an inter-agency body (COSC) to address violence against women. Otherwise women's equality and human rights are subsumed in the wider equality and human rights machineries. The National Women's Council of Ireland, which receives state funding (recently cut by 35 per cent within a context of public expenditure cuts), operates as a watch dog on domestic policy issues but less so in international policy domains. ${ }^{41}$ Until its recent cessation, the organisation Banúlacht had for ten years been the sole feminist, gender and development organisation monitoring Irish Aid's activity from a critical gender perspective. ${ }^{42}$ As will be highlighted in the next section, the links between Irish Aid staff responsible for the gender equality and women's movement actors appear to be very tenuous. While rhetorically, Irish Aid gender equality policy embraces feminist values and practices (pre-emption), women's movement actors are rarely included in policy formation processes and when they are their input is not generally acted upon (co-optation).

In summary, this section has explored different policy process concepts and identified those most pertinent to understanding the conditions of adoption of gender mainstreaming by Irish Aid and interpreting the subsequent poor record of implementation. This includes recognition of the limiting effects on policy outcomes of soft coercion, imitation and competition in the policy diffusion process through which Irish Aid came to adopt a gender equality policy. In addition, I have pointed to the value of a broadly social constructivist perspective that foregrounds the role of meaning construction in closing off and limiting possibilities for action and in determining whether a policy issue is low or high salience. A corollary is that low-salience policy issues require strong policy entrepreneurs to counter the

38 Melissa Haussman and Birgit Sauer, 'Introduction: women's movements and state restructuring in the 1990s', in Melissa Haussman and Birgit Sauer (eds), Gendering the state in the age of globalization: women's movements and state feminism in postindustrial democracies (Lanham, UK, 2007), 1-17.

${ }^{39}$ Haussman and Sauer, 'Introduction: women's movements and state restructuring in the 1990s', 8.

${ }^{40}$ Haussman and Sauer, 'Introduction: women's movements and state restructuring in the 1990s', 6.

${ }^{41}$ See www.nwci.ie.

${ }^{4}$ See www.banulacht.ie. 
impact of negative perception. Further, a process-oriented understanding of gender mainstreaming, which appreciates the role of administrative routines and the discretionary power of bureaucrats, offers an important analytical perspective when accounting for the successes and failures of the policy, including in Irish Aid. Finally, theorisations of the relationship between feminist/women's movement actors and the state are particularly salient in explaining the weak outcomes to date that characterise the story of gender mainstreaming in Irish Aid. The following section reviews the content of Irish Aid's gender equality policy and its approach to gender mainstreaming. It offers a close examination of key reports on Irish Aid's efforts to date to implement the policy via gender mainstreaming and draws on the concepts discussed in this section to explain and interpret the findings.

\section{IRISH AID'S GENDER EQUALITY POLICY}

As noted, the process of global diffusion of gender mainstreaming gathered momentum around the Fourth World Conference on Women (Beijing, 1995). Irish Aid was relatively slow, therefore, to adopt its gender equality policy in 2004, which explicitly embraces gender mainstreaming, declaring that 'gender equality is the goal: gender mainstreaming is the strategy'. ${ }^{43}$ Reflecting the power of soft coercion, a number of factors combined at this time to bring additional pressure to bear on Ireland, to be seen to be proactive on gender equality issues internationally. In particular, the ten-year review of progress on implementation of the ICPD Programme of Action (Cairo +10) took place in 2004. At the same time, Ireland held the EU Commission presidency for the first half of the year, which meant that Irish ministers and officials were in the spotlight as they represented the EU at the Cairo +10 forum, as well

as at the annual session of the UN Commission on the Status of Women, the body responsible for monitoring the progress of governments on implementation of the Beijing Platform for Action. Undoubtedly, this confluence of events served as a particular goad to Irish Aid (then Development Cooperation Ireland) to produce a gender equality policy to coincide with these events.

From a feminist human rights or 'gender and development' perspective, Irish Aid's Gender Equality Policy reads like an exemplary endorsement of a transformative 'twin track' approach to gender mainstreaming and a vision of 'indivisible' human rights in women's lives. The content of the Foreword to the policy warrants particular attention. As stated by the responsible minister of state of the day, Tom Kitt, it indicates the political commitment and leadership behind the policy - rhetorically at least. In this case, the minister states unequivocally the government's commitment to put gender equality at the centre of Ireland's 'development cooperation programme'. ${ }^{44}$ The Foreword asserts: 'It is impossible to eliminate poverty without having a clear and unambiguous commitment to gender equality' and, further, that 'gender equality is an important goal in its own right and its achievement is crucial for sustainable human development'. This commitment is placed within a framework of attainment of human rights. The policy's scope, the minister notes, includes 'three areas for the advancement of gender equality for women and men: the full achievement of human rights; equal access to resources and services; and equal participation in political and economic decision-making'. This grounding in international commitments is also clearly stated in the policy text with explicit reference to the UN Convention on the Elimination of All Forms of Discrimination against Women (CEDAW), the Beijing Platform for Action, and the Millennium Development Goals. ${ }^{45}$ The Foreword, therefore, signals an embrace of a feminist analysis of the roots of the problem, which in hindsight might be read as a 'pre-

\footnotetext{
${ }^{43}$ DFA DCI, Gender Equality Policy, 8.

44 DFA DCI, Gender Equality Policy, 7.

45 DFA DCI, Gender Equality Policy, 11-12.
} 
emptive' incorporation of feminist language as defined in the RNGS framework. It recognises that women's equal access to and participation in development is often thwarted, especially by their concentration and 'invisibility' in unpaid and caring work, obstacles to their participation in decision-making at various levels, discriminatory laws and customs, as well as by the prevalence of different forms of violence against women-from trafficking to rape - and women's related vulnerability to HIV/AIDS.

Similarly, endorsing the policy's 'twin track' approach the Foreword declares: 'The Policy does not stop at identifying what must be done to achieve gender equality. It also addresses how it should be done', that is, by 'endorsing a strategy of mainstreaming'. ${ }^{4}$ Further, according to the Minister, the model of mainstreaming envisaged by the policy must be informed by principles of 'partnership and dialogue' and 'better analysis and understanding of the...realities facing women and men in developing countries'.

Significantly, from a feminist perspective, the minister stresses that mainstreaming 'does not replace the need to promote women-specific interventions aimed at eliminating gender equality'. Indeed, much of the content (e.g., definitions of 'gender', 'gender equality', 'women's empowerment', 'gender mainstreaming', 'gender analysis') might have been taken from a feminist gender and development text-book. However, the text on what the policy aims to achieve, while rhetorically strong, is very light on detail. It includes just one policy goal: 'To support the achievement of gender equality as an essential component of sustainable development' ${ }^{47}$ This goal is divided into three ambitious but vague policy objectives, to: 'advance equal rights for women and men', 'eliminate gender inequalities in access to, control of and benefit from resources and services' and 'promote gender equality in political and economic power'.

The policy's most concrete commitments to action are highlighted in the Introduction. It promises 'robust institutional arrangements' and recognises the 'responsibility of all DCI staff for delivery of policy goals'. ${ }^{48}$ More details on fulfilling these commitments are provided later in the document, including: the formation of a cross-directorate, managementlevel, 'gender team' within Irish Aid headquarters; the appointment of a gender advisor and senior development specialist 'with specialist gender competence'; and the creation of an embassy-level team structure, including assigned gender advisors. ${ }^{49}$ The policy also calls for the preparation by the gender team of a three-year Action Plan (within six months) specifying annual, time-bound targets and reporting procedures, and the requisite dedicated budget. ${ }^{50}$

Almost one decade since the adoption of the Gender Equality Policy, what can be said about its implementation and impact within Irish Aid? It is beyond the scope of this article to consider in detail whether, and in what ways, the Gender Equality Policy has been implemented across Irish Aid programming at partner country level. Rather, in the following sub-sections, I review and critically discuss what has been reported by Irish Aid at an institutional level in relation to meeting the policy's concrete commitments outlined above.

\section{Progress on institutionalisation of the Gender Equality Policy}

In 2007, gender and development practitioner Maeve Taylor noted:

The Gender Equality Policy was launched in 2004 as a three year policy, but the action plan promised - which is central to the implementation of the

\footnotetext{
${ }^{46}$ DFA DCI, Gender Equality Policy, 7, emphasis added

${ }^{47}$ DFA DCI, Gender Equality Policy, 14.

48 DFA DCI, Gender Equality Policy, 10.

49 DFA DCI, Gender Equality Policy, 26.

${ }^{50}$ DFA DCI, Gender Equality Policy, 17 and 27.
} 
policy—has not been published. Without an action plan, it is unclear what the indicators of success are and which evaluation frameworks and mechanisms are in place. ${ }^{51}$

More than five years on, Taylor's comment still stands. A cross-divisional, senior management Gender Team along the lines envisaged in the policy has not been formed. Irish Aid's 'Gender equality policy: review report' (2010) indicates that there is one 'Full time gender advisor at HQ' and that there are 'Gender advisors/officers/focal points now in all Embassies' ${ }^{52}$ A second senior development/gender specialist not been appointed or assigned in headquarters and, while the designation of gender officers in embassies looks like a positive step, in the absence of a coherent, resourced and sustainable team structure, the effectiveness of this measure will be inevitably very uneven. Irish Aid has never published a gender equality Action Plan. Nor has Irish Aid enforced its own requirement that partners in receipt of funding under the Multiannual Programme Scheme should submit gender mainstreaming action plans. ${ }^{53}$

More generally, while information in the public domain regarding the organisational structure of Irish Aid is sparse, what is available suggests that the gender policy and perspectives continue to be largely hidden, diluted and/or marginalised within Irish Aid. The Irish Aid Organisation Chart in the most recent OECD peer review of Irish Aid ${ }^{54}$ indicates a structure headed by the minister of state with a director general and deputy director occupying the next two steps. Under the leadership of the director and/or deputy director are 12 sections. ${ }^{55}$ Notably, the words 'women' or 'gender'do not appear anywhere on the chart; neither word appears in the title of any section nor do they appear at all in the list of dozens of areas, projects and briefs enumerated in each section column. The term 'mainstreaming' appears as an element in the 'Policy Planning and Effectiveness' section. It is also important to note that gender equality is treated by Irish Aid as one of four cross-cutting issues to be mainstreamed throughout Irish Aid activities and programmes. ${ }^{56}$ This invisibility of gender equality in the organisational structure, however, is indicative of its low salience and raises immediate questions about the adequacy and effectiveness of Irish Aid's mainstreaming strategy overall and the strength of its gender dimension in particular.

Commenting on Irish Aid's ways of working to implement mainstreaming, the OECD peer review report notes that 'a team approach [is] in place to advance cross-cutting areas

${ }^{51}$ Maeve Taylor, 'Gender and the White Paper on Irish Aid', Trócaire Development Review (2007), 65-77: 75, available at:

http://www.trocaire.org/sites/trocaire/files/pdfs/tdr/DR2007_genderandthewhitepaperonIrishaid.pdf (10 June 2013).

52 Sinéad Murray, Aisling Swaine and Áine Doody, 'Gender equality policy: review report' (Dublin: Irish Aid/Government of Ireland, 2010), available at: http://www.irishaid.gov.ie/Uploads/Gender\%20Equality\%20Policy\%20Review.pdf (10 June 2013).

${ }^{53}$ Murray, Swaine and Doody, 'Gender equality policy: review report', 27.

54 Organisation for Economic Co-operation and Development, Ireland: Development Assistance Committee (DAC) Peer Review (Paris: OECD, 2009); hereafter cited as OECD, Ireland: DAC peer review, available at: http://www.oecd.org/dataoecd/50/1/42704390.pdf (10 June 2013).

55 These are: Civil Society; Multilateral EU; Public Information and Development Education; UN, World Bank, IFIs; Corporate Services Liaison CPL. General; Programme Countries I; Programme Countries II; CPL Finance; Emergency and Recovery; Policy Planning and Effectiveness; Evaluation and Audit; Thematic Sectors and Special Programmes. The same list of sections is also provided on the Irish Aid website updated in May 2011, see: http://www.irishaid.gov.ie/about_structure.html (16 August 2013).

56 Department of Foreign Affairs, White Paper on Irish Aid (Dublin, 2006), available at: http://www.irishaid.gov.ie/whitepaper/assets/White\%20Paper\%20English.pdf (10 June 2013). 
(gender equality, environment, governance and HIV/AIDS).${ }^{57}$ While recognising that mainstreaming is an 'evolving' and 'strong feature' of Irish Aid programming, ${ }^{58}$ the report also makes recommendations, which are indicative of major weaknesses in Irish Aid's implementation of mainstreaming and which need to be addressed if the strategy is to be amenable to evaluation in the first instance. This includes the need for Irish Aid to: 'capture and document lessons and outcomes on mainstreaming through reporting systems, using key indicators to measure impact' ${ }^{59}$ These observations echo the recommendations of feminist critics like Moser, who continue to argue that gender mainstreaming can be strengthened through technical improvements. ${ }^{60}$ Moreover, the report expressly encourages Irish Aid to 'adequately resource its initiatives on gender and environment to match its commitments'. ${ }^{61}$

At first glance, the existence of a dedicated gender equality budget line in Irish Aid from 2005 appears to be an important gain for gender equality. Currently, this is used to: 'support networking, research, learning knowledge dissemination and capacity development on gender equality with a specific focus on GBV [gender-based violence], gender and hunger and gender and aid effectiveness'. ${ }^{62}$ However, this does not appear to be a new allocation, and rather is a re-designation of a pre-existing 'women in development' budget line. Moreover, the proportion and the level of funding allocated to the Gender Equality Budget line have both been very modest and, most recently, the level of funding has dropped dramatically in the context of Ireland's protracted economic crisis. In 2005, the gender equality budget was $€ 0.5$ million, about 0.1 per cent of the total overseas development aid (ODA) budget of $€ 578.5$ million. ${ }^{63}$ The most recent figure for 2010 reflects about the same proportion: $€ 0.8$ million or 0.12 per cent of a total ODA budget of $€ 676$ million. ${ }^{64}$ This compares, for example, to €6.6 million or 1 per cent of the total bilateral ODA budget that was allocated to 'development awareness' in the same year. The fact that Irish Aid allocated ten times more to development awareness in 2010 than it did to support its gender equality policy capability does not suggest that gender equality is a high priority within the organisation.

Data regarding the share of expenditure across all Irish Aid programmes deemed to be 'in support of gender equality and women's empowerment', is also useful in gauging the success or otherwise of gender mainstreaming. For example, in 2008, the peak year in this period for gender equality expenditure, using OECD DAC sector codes, Irish Aid indicates that it allocated 0.8 per cent to gender equality and women-focused initiatives, that is, $€ 7.8$ million of $€ 920.7$ million total ODA. ${ }^{65}$ At the same time, the authors of the report suggest this estimate is low. Citing internal Irish Aid tracking figures, they estimate that when all expenditures on projects where gender equality as a 'principal' or 'significant' objective are included, the actual percentage ranges from 5.14 to 35 per cent. ${ }^{66}$ This position is also articulated in the most recent report on 'Aid in support of gender equality and women's

57 OECD, Ireland: DAC peer review, 48.

58 OECD, Ireland: DAC peer review, 11.

59 OECD, Ireland: DAC peer review, 11.

${ }^{60}$ Moser, 'Has gender mainstreaming failed?'.

${ }^{61}$ OECD, Ireland: DAC peer review, 14.

62 Department of Foreign Affairs, 'Annual monitoring report on gender equality-2010: report from Irish Aid's gender network' (Dublin, 2010), 19, available at: http://www.dochas.ie/Shared/Files/2/Annual_Monitoring_Report_on_Gender_Equality-2010.pdf (10 June 2013).

63 Department of Foreign Affairs, White Paper on Irish Aid, 68.

${ }^{64}$ Department of Foreign Affairs, 'Annual monitoring report on gender equality 2010', 65.

${ }^{65}$ Murray, Swaine and Doody, 'Gender equality policy: review report', 36.

${ }^{66}$ Murray, Swaine and Doody, 'Gender equality policy: review report', 36. 
empowerment' ${ }^{67}$ It indicates that in 2009 and 2010, 53 per cent and 57 per cent of Irish Aid's 'sector allocable aid' was allocated in support of initiatives in which gender equality was a 'significant' or 'principal objective'. ${ }^{68}$

This, however, overstates the case. There are problems with the distinction between 'significant' and 'principal'. According to the OECD, 'principal objective' means that 'gender equality is an explicit objective of the activity and fundamental in its design', while 'significant objective' means that gender equality is 'an important, but secondary, objective and activity' ${ }^{69}$ Aside from the glaring problem of the absence in Irish Aid to date of any systematic reporting using appropriate indicators and impact measurements, the value of OECD's 'significant objective' category is extremely doubtful as an indicator of meaningful gains in gender equality and women's empowerment. Even accepting these figures, in a policy context where gender equality has been declared to be a cross-cutting issue and where gender mainstreaming has been embraced as the chosen strategy, the fact that more than 40 per cent of initiatives funded by Irish Aid do not include gender equality even as a secondary objective should be a cause of concern. In any event, whether or not a sector initiative (e.g. health or education) includes gender equality as a 'principal objective' is clearly a more appropriate indicator of the success or otherwise of gender mainstreaming across Irish Aid. On this count, Irish Aid has a weak record with only 3.5 per cent of 'sector allocable' funds going to initiatives with a principal focus on gender equality and women's empowerment in 2010. Within Europe, unsurprisingly, Sweden sets a better example where, also in 2010, 10 per cent of its 'sector allocable' aid went to initiatives that had gender equality as a principal objective. ${ }^{70}$ Canada, however, was by far the leader in this regard in 2010, with approximately 30 per cent of its 'sector allocable' aid going to 'principal objective' expenditure. $^{71}$

Furthermore, the share of 'non-sector allocable' aid received by women's equality organisations is also an important indicator of the depth of Irish Aid's commitment to twintrack gender mainstreaming, which calls for support to dedicated initiatives to advance women's empowerment in tandem with incorporating women and gender perspectives into mainstream policy domains. In 2010, only 5 per cent of Irish Aid's 'non-sector allocable' aid (US\$10 million out of US\$194 million) was received by women's equality organisations. ${ }^{72}$ This amounts to about 1.2 per cent of Irish Aid's total ODA budget. Approximately half of this (€3.66 million) is estimated to have gone to gender-based violence programming. ${ }^{73}$ The reluctance to fund women's equality organisations is further confirmation of the weak links that prevail between Irish Aid and women's movement actors. While the share to women's equality organisations is very small, especially when considered in relation to the scope and strength of Irish Aid's stated policy commitment to advancing gender equality across its programming, it is on a par with the proportion that the United Kingdom and the United States give to women's equality organisations. This could be read as a mimicking of countries that Irish policy actors perceive to be close to them ideologically or psychologically. Indeed, the proportion of direct funding to women's equality organisations appears to be extremely small overall, with most countries allocating considerably less than 5 per cent to this category. This confirms Rosalind Eyben's observation of a post-Beijing

${ }^{67} \mathrm{OECD}$, 'Aid in support of gender equality and women's empowerment'.

$68 \mathrm{OECD}$, 'Aid in support of gender equality and women's empowerment', 15.

69 OECD, 'Aid in support of gender equality and women's empowerment', 15.

70 OECD, 'Aid in support of gender equality and women's empowerment', 25.

$71 \mathrm{OECD}$, 'Aid in support of gender equality and women's empowerment', 8 .

72 OECD, 'Aid in support of gender equality and women's empowerment', 15.

73 DFA, ‘Annual monitoring report on gender equality 2010', 19. 
failure to sustain governments' commitment to women's empowerment. ${ }^{74}$ Spain was the notable exception in 2010, allocating about 12.5 per cent (US\$149 million of US\$1185 million) of its 'non-sector allocable' aid to such organisations. ${ }^{75}$

In summary, the evidence of Irish Aid's institutionalisation of, and resource allocation to, gender equality and gender mainstreaming, in the years following the adoption of its gender equality policy, suggests a very weak commitment. This includes: the complete invisibility of gender equality in its organisational structure and public representations thereof; an extremely small gender equality budget line ( 0.12 per cent of ODA); a very low proportion of funding allocated to projects that have gender equality as a principal objective (3.5 per cent of ODA); and a very low proportion of ODA funding received directly by women's equality organisations ( 1 per cent of ODA). The evidence suggests, therefore, that gender equality is a low-salience and low-priority issue from the point of view of the most senior decision makers in Irish Aid. This record supports the interpretation that Irish Aid's adoption of a gender equality policy and gender mainstreaming is best understood as a reflection of Ireland's instrumental use of gender equality issues to ensure that it is seen to be saying all of the right things on gender equality. Arguably, it does so, not from a principled commitment to gender equality, but to protect or enhance its reputation for the duration of a particular phase in the international spotlight. The following section considers in more depth Irish Aid's reporting on its own record of substantive implementation of its gender equality policy. This brings into focus the role of key bureaucrats and the implications of the weakness of links with women's movement actors.

\section{Progress on substantive implementation of the Gender Equality Policy}

In the absence of an Action Plan, Irish Aid's 'Gender equality policy: review report' (2010) offers a valuable window on how Irish Aid (especially its staff responsible for driving implementation of the Gender Equality Policy) understands the scope and significance of the policy within Irish Aid and how it views its progress and the ongoing challenges faced in progressing implementation. ${ }^{76}$ The 'review report' offers quite a critical account of Irish Aid's own performance in implementing the Gender Equality Policy, including several recommendations for improved implementation. In contrast, the first 'Annual monitoring report on gender equality - 2010: report from Irish Aid's gender network' consists of largely positive narrative descriptions of selected activities under the headings of: contributions to policy objectives; partners and strategies; and linking with other sections of DFA. It also provides a brief comment on internal mainstreaming, expenditure on gender equality, and priorities for 2011-12. Differences in the nature and scope of these two reports produced in the same year, however, are significant and important to consider. The first, which is based on a reasonably detailed review process ${ }^{77}$ (with substantial external consultant input), is framed as the output of an 'internal review' that sought to: 'facilitate reflection at HQ and field level to identify key areas of progress and challenges in the implementation of the policy goals, objectives and strategies with the aim of updating and strengthening the implementation of current policy' ${ }^{78}$

${ }^{74}$ Eyben, 'Subversively accommodating'.

75 OECD, 'Aid in support of gender equality and women's empowerment', 24.

${ }^{76}$ Murray, Swaine and Doody, 'Gender equality policy: review report'.

77 The review process entailed 'an examination of documentation, consultations with staff and a small number of civil society organisations, and a study of the external environment undertaken by the independent organisation, Bridge. Data from a review of Irish Aid's progress towards addressing gender equality undertaken in 2003 provided a baseline against which key areas of progress and continuing challenges were viewed', see Murray, Swaine and Doody, 'Gender equality policy: review report', 2.

${ }^{78}$ Murray, Swaine and Doody, 'Gender equality policy: review report', 10. 
The 'Annual monitoring report', in contrast, is presented as an output of Irish Aid's Gender Equality Network 'drawing on annual reports received from programme countries as well as inputs from HQ Sections and partner reports'. ${ }^{79}$ As such, the latter report is based on a less thorough process than the former and arguably is the less critical and 'independent' of the two reports. Nonetheless, its title and the recent publication in a similar format of the 2011 annual report ${ }^{80}$ indicate that Irish Aid intends to continue with a loose narrative approach for the purposes of ongoing monitoring and evaluation of its gender equality policy. This is a good example of a window in which the discretion of key bureaucrats is pivotal. As noted, feminist champions of gender mainstreaming who retain a commitment to its viability as a transformative tool stress the imperative of developing transparent, systematic and detailed mechanisms to monitor and evaluate progress. The first annual monitoring report does not fulfil these functions at all. In a context such as Irish Aid, where gender mainstreaming has been adopted but has low salience in the organisation, a great deal rests on whether or not the bureaucrats with responsibility for driving the policy are in a position to act as policy entrepreneurs and to push for more ambitious approaches to implementation, including seeking greater shares of resources internally.

The remainder of this sub-section draws largely on the 'review report', which is a reasonably critical review of Irish Aid's gender equality policy ${ }^{81}$ However, recognising the report is a form of socially-constructed knowledge, it is also important to flag its point of departure, terms of reference and apparent 'no-go' areas. While the Introduction to the report notes the policy goal, policy objectives, and twin-track gender mainstreaming strategy of the Gender Equality Policy, it does not dwell at all on the content of the policy per se. The stated terms of reference for the review include 'questions under the DAC evaluation framework' and these are used to structure elements of the Conclusion (i.e., effectiveness, relevance, sustainability, impact). ${ }^{82}$ More significantly, however, the review draws its baseline data for assessing progress from the findings of a previous 2003 review of Irish Aid's record on gender equality. ${ }^{83}$ While this approach yields interesting if not very encouraging data regarding Irish Aid's progress on gender equality in the seven-year period from 2003 to 2010, it also allows the review to sidestep Irish Aid's most obvious implementation failure: not producing a three-year action plan within six months of adopting the Gender Equality Policy, as explicitly promised in the 2004 policy document. Except for an oblique reference to the absence of an action plan, which is noted as a criticism made by the no-longer operating feminist organisation, Banúlacht, the report is silent on the lack of an action plan. ${ }^{84}$ Nor does the review systematically consider whether and how the operating principles of the Gender Equality Policy are being observed across Irish Aid including, for example, the requirement that all Irish Aid activities have clear gender equality objectives, that women's empowerment is central to implementation of the policy, and that senior management across Irish Aid should promote gender equality as an institutional mandate. The decision not to organise the review around these objectives, operating principles and action commitments of the Gender Equality Policy itself raises major questions about the status and salience of the policy and the depth of commitment to its substantive realisation.

${ }^{79}$ DFA, 'Annual monitoring report on gender equality 2010', 5 .

${ }^{80}$ Department of Foreign Affairs and Trade, 'Annual monitoring report on gender equality 2011: report from Irish Aid's Gender Network' (Dublin, 2012), available at:

http://www.irishaid.gov.ie/media/irishaid/allwebsitemedia/20newsandpublications/publicationpdfsenglish/annua 1-monitoring-report-on-gender-equality-2011.pdf (28 July 2013).

${ }^{81}$ Murray, Swaine and Doody, 'Gender equality policy: review report'.

82 Murray, Swaine and Doody, 'Gender equality policy: review report', 38.

${ }^{83}$ Murray, Swaine and Doody, 'Gender equality policy: review report', 10.

${ }^{84}$ Murray, Swaine and Doody, 'Gender equality policy: review report', 16. 
An apparent strength of the review is the central involvement of an external consultant. This is an example of Irish Aid's regular use of gender experts in its gender mainstreaming policy formation (the original Gender Equality Policy was also drafted by an external consultant). On the plus side, this can bring a degree of independent scrutiny to the process. Potentially it also brings opportunities for policy learning that can strengthen policy outputs and encourage policy innovation. More generally, it confirms the consensus among diffusion theorists that diffusion relies on the input of experts and recognised epistemic communities. Ultimately, however, the impact of such learning, and whether or not experts have been able to act as effective policy entrepreneurs in the case of Irish Aid, is revealed in the extent to which their inputs are acted upon. Clearly, in the case of the original process to draft the Gender Equality Policy itself, the efforts of the external expert to ensure that an action plan would be produced and systematically monitored, were not successful. Similarly, the wide gap in the 'review report' between the harshness of the criticisms it articulates regarding failures to implement the policy, and the mildness of the recommendations it actually endorses, suggests the relatively weak influence of the external contributor in what is ultimately an internal Irish Aid report.

Regarding, the specific findings of the 'review report', in addition to the 'gender equality budget line' and the designation of gender advisors in embassies and headquarters noted above, 'strengthened gender analysis in Irish Aid's Country Strategy Papers' is highlighted as a key achievement in the report. It also notes that 'team-working as well as leadership, the strategic use of external expertise and strengthened [management for development results] have been key to progressing gender equality objectives' ${ }^{85}$ Securing increased attention and resources to Gender Based Violence (GBV) is underlined as an especially significant success, including Irish Aid's membership in the Joint Consortium on Gender Based Violence, the allocation of $€ 4.7$ million of funding to GBV in 2008, and the inclusion of GBV as an 'integral component' of programming in 'nearly all programme countries' ${ }^{86}$ Other claims of success are the achievement of greater coherence and crosssector co-operation, principally Irish Aid's active participation in the development of a national action plan on UN Security Council Resolution 1325 co-ordinated by the Conflict Resolution Unit of DFA. Underlining the relevance of 'competition' as a key factor in diffusion of the aid effectiveness agenda, the 'review report' foregrounds the Managing for Development Results (MfDR) approach. In positive tones, it welcomes the opportunity that MfDR has offered for 'strengthening a focus on gender equality across the organisation'. ${ }^{87}$ Finally, Irish Aid's gender-focused contributions to international policy dialogue are also presented as key successes of its gender equality policy, including contributions made via participation in the OECD DAC 'Gendernet' to put gender on the agenda of the High Level Forum on aid effectiveness. ${ }^{8}$ Irish Aid's support for the new UN gender entity-UN Women - through its Multilateral Section is another example highlighted.

On the other side of the balance sheet, however, the 'review report' underlines numerous major deficiencies in Irish Aid's implementation of its gender equality policy, including inadequacies in: (i) internal understanding and application of its core concepts; (ii) quality of dialogue with civil society organisations; (iii) country strategy paper processes; (iv) staff capacity development; and (iv) monitoring expenditure on gender equality. First, the report finds that 'not all staff members across the organisation fully understand the concepts of gender equality, empowerment or transformative approaches contained in the Gender

\footnotetext{
85 Murray, Swaine and Doody, 'Gender equality policy: review report', 3.

${ }^{86}$ Murray, Swaine and Doody, 'Gender equality policy: review report', 3.

${ }^{87}$ Murray, Swaine and Doody, 'Gender equality policy: review report', 3.

88 OECD, 'Paris Declaration and Accra agenda'.
} 
Equality Policy and are unsure of how to apply them to their work', and that 'awareness of the policy among staff is very limited' ${ }^{89}$ In particular, in applications of the policy, the authors observe a primary focus on meeting 'practical gender needs', for example, in relation to health, education and so on, rather than on 'strategic gender needs', including, for example, addressing women's unequal access to decision making. ${ }^{90}$ Moreover, the report notes that Irish Aid's commitment to a twin-track approach to gender mainstreaming 'is not set out clearly enough within the policy and needs to be clearly elaborated through training/guidance for staff'.$^{91}$

Second, the report highlights that Irish Civil Society Organisations (CSOs) are very dissatisfied with the lack and/or poor quality of dialogue with them on gender equality, which is described as 'sporadic and ad hoc with little advance notice'. ${ }^{92}$ It notes that the Joint Consortium on Gender Based Violence, which includes Irish Aid, the Irish Defence Forces and Ireland's main humanitarian and human rights NGOs (but does not include any women's equality and rights organisations), is the only forum where dialogue on gender-related issues takes place. Importantly, the report suggests that the Consortium 'may, to some degree, have occupied the space that could be available for dialogue on wider gender equality issues' and it notes that local CSOs are 'unaware of where, when and how Irish Aid engages in policy dialogue on gender equality at international level and would like more opportunity to comment on the development of national positions'. ${ }^{93}$ These points underline once again a record of very poor links with women's movement actors, which, according the RNGS framework is predictive of an underwhelming record of implementation of feminist policies, such as gender mainstreaming.

Third, regarding Country Strategy Paper (CSP) processes, the report underlines 'a continuing lack of sex-disaggregated data being used to inform analysis' and inconsistent application of gender analysis, as well as 'inconsistent reporting on gender equality and in some cases no mention of gender at all' in CSP annual reports. ${ }^{94}$ Recognising that 'managing for results' offers 'significant opportunities to more effectively contribute to the implementation of the Gender Equality Policy', the report stresses that achieving this requires that 'a strong [gender] analysis underpins CSPs and that gender indicators are explicitly included'.${ }^{95}$ However, neither of these conditions was found to be in place. Fourth, and related to the first point, the report finds that the "majority of staff at HQ and in missions have not received any training on gender equality... were not familiar with the Gender Equality Policy' and yet 'are expected to be competent in gender mainstreaming' ${ }^{96}$ Finally, with respect to monitoring expenditure on gender equality, the report notes that the actual level of expenditure for gender equality and women's empowerment is unclear, and perhaps 'underreported', due to the limited understanding across Irish Aid of gender-expenditure tracking methodologies. ${ }^{97}$ Regarding the gender equality budget line, the report notes that it is 'small but strategically important' but cautions that 'its current role in "filling gaps" in programme responses may not be the most strategic use of the budget line'. ${ }^{98}$

\footnotetext{
${ }^{89}$ Murray, Swaine and Doody, 'Gender equality policy: review report', 3, 37.

${ }^{90}$ Murray, Swaine and Doody, 'Gender equality policy: review report', 3.

${ }^{91}$ Murray, Swaine and Doody, 'Gender equality policy: review report', 3.

92 Murray, Swaine and Doody, 'Gender equality policy: review report', 4.

93 Murray, Swaine and Doody, 'Gender equality policy: review report', 4.

94 Murray, Swaine and Doody, 'Gender equality policy: review report', 3-4, 25.

95 Murray, Swaine and Doody, 'Gender equality policy: review report', 25.

96 Murray, Swaine and Doody, 'Gender equality policy: review report', 4.

97 Murray, Swaine and Doody, 'Gender equality policy: review report', 4.

98 Murray, Swaine and Doody, 'Gender equality policy: review report', 37.
} 
Despite these far-ranging criticisms, the report's recommendations (repeated in the Annual Monitoring Report) are extraordinarily weak. The strongest of these are that Irish Aid should: set out clearly the twin-track approach to gender mainstreaming; develop a 'results framework' as the basis of an annual report for senior management; and ensure a more systematic approach to using gender analysis and sex disaggregated data. Significantly, it names three priority areas for gender mainstreaming, including: gender-based violence, hunger and aid Effectiveness, with the greatest emphasis on the last two. It recommends that annual reporting on the Gender Rquality Policy should include an analysis of expenditure trends on both specific initiatives and gender mainstreaming. Regarding resources, very conservatively, it recommends maintenance of the current allocation of human resources and the allocation of a junior professional intern to the gender portfolio.

It is difficult not to surmise that the 'recommendations' are a simple summation of what Irish Aid had already decided to do irrespective of the review's findings. The failure to mention an action plan and the lack of specific recommendations on what the annual monitoring mechanism should entail are striking gaps. But most importantly, given the scale of what is required to address the massive gaps in training across the organisation on concepts, technical tools of mainstreaming and gender data management and analysis, it is extraordinary that the report does not include a recommendation to substantially increase the gender equality budget line. Similarly, the failure of the report to make recommendations in relation to targeted allocations of ODA to women's equality organisations and activities that promote gender equality and women's empowerment is also remarkable. The weakness of the recommendations, given the scale of what remains to be achieved, suggests that Irish Aid is not an organisation where gender mainstreaming policy entrepreneurs are present in sufficient numbers to champion a transformative vision of gender equality and gender mainstreaming. This is not to say that the small number of people assigned to the gender portfolio in Irish Aid is not having an impact. Undoubtedly, as Lipsky suggests, they believe with good reason that they are 'doing the best they can under adverse circumstances'. Rather, it points to the confluence of structural obstacles militating against the meaningful implementation of the Gender Equality Policy via gender mainstreaming in Irish Aid. Not least among these is the fact that the role of the policy, from the perspective of the senior decision maker, is principally to give the semblance of a commitment to gender equality, as and when this serves to enhance Ireland's reputation in foreign affairs, rather than to ensure the achievement of gender equality outcomes per se in development policy contexts.

\section{CONCLUSIONS}

This article has provided a critical review and discussion of the status and record of implementation of Irish Aid's gender equality policy, drawing on key concepts in policy process theory and feminist scholarship on gender mainstreaming. I have argued that, overall, Irish Aid's record of meaningful implementation is extremely weak. Given that women in development and gender equality have been on the agenda of Irish Aid or its predecessor in some form since 1986, the achievements to date are extremely discouraging. The diffusion of gender mainstreaming post-Beijing was expected to galvanise new interest and commitment on the part of governments to take bolder steps to advance gender equality as an end in itself and throughout mainstream policy areas. That two key Irish Aid reviews, in 2003 and in 2010, draw very similar conclusions about the failures of gender mainstreaming in the organisation is a striking comment on the low priority that Irish Aid ultimately accords to gender equality. Why does an organisation such as Irish Aid adopt policies that are indicative of a very strong commitment to gender quality but do so little in practice, and get away with it? 
In this article I have flagged several possible explanations. First, I suggest that the adoption by Irish Aid of policies that rhetorically are very strong on gender equality reflects effective global policy diffusion. However, given Ireland's very weak position in the international order, this needs to be read through a lens of soft coercion, imitation and competition, rather than as benign social construction and policy learning. Under such conditions, Ireland tends to overplay its commitment at a rhetorical level in order to enhance its reputation. Because, however, the commitments are not as deeply rooted as they might be if the gender agenda was embraced proactively as a 'good idea', the most senior decision makers are principally interested in securing a strong veneer of commitment to gender equality rather than in gender equality outcomes. This explains the persistence of stronglyworded policies and consistently poor evaluations of performance when carried out by semiindependent reviewers. Second, the weakness of state feminism in Ireland, and the correspondingly weak links between, on the one side, bureaucrats within the state who are responsible for implementing gender equality and, on the other, women's movement actors, is consistent with the poor translation of feminist ideas into state policy. Third, where policies (such as those linked to feminist and gender equality agendas) have low salience and are unpopular, ambitious and effective, policy entrepreneurs can compensate and offset these disadvantages. In the case of the Gender Equality Policy in Irish Aid, in addition to weak links with women's movements actors, there are too few policy entrepreneurs who might use their discretionary power to push out boundaries and press for greater shares of resources to gender equality and gender mainstreaming activities. Finally, the current burgeoning diffusion of the policy of 'management for development results' poses a major threat to human rights- and equality-based approaches to development, including gender mainstreaming. For all of these reasons, the Gender Equality Policy in Irish Aid is at risk of continued dilution and perhaps even disappearance. 